$\begin{array}{ll}\text { Date: } & \text { June 25, } 2015 \\ \text { Revised version for: } & \text { Journal of Membrane Science }\end{array}$

\title{
Influence of solution concentration and salt types on the performance of reverse electrodialysis cells
}

\author{
Xiuping Zhu, Weihua He, Bruce E. Logan* \\ Department of Civil and Environmental Engineering, The Pennsylvania State University, University Park, \\ Pennsylvania 16802, United States \\ *Corresponding Author. Telephone: +1 814863 7908. Fax: +1 814863 7304. E-mail: blogan@ psu.edu.
}

\begin{abstract}
The influence of salt concentrations on the performance of reverse electrodialysis (RED) stacks has rarely been investigated using thermolytic salts such as $\mathrm{NH}_{4} \mathrm{HCO}_{3}$, that can be regenerated using waste heat and can be set at any desired concentration below saturation limits. Here, power densities produced by a RED stack were first investigated using different $\mathrm{NaCl}$ concentrations, and then tested using $\mathrm{NH}_{4} \mathrm{HCO}_{3}$. The power produced by the RED stack increased with $\mathrm{NaCl}$ concentrations from $0.6 \mathrm{M}$ to $3.6 \mathrm{M}$ in the $\mathrm{HC}$ (high concentration) solution, but it did not increase at higher salt concentrations due to limited ion exchange membrane capacity. $\mathrm{NaCl}$ concentrations larger than $0.14 \mathrm{M}$ in the LC (low concentration) solution decreased power primarily as a result of lower salinity ratios $(<25)$. However, LC concentrations up to $0.14 \mathrm{M}$ $\mathrm{NaCl}$ did not appreciably affect power output due to a trade-off between decreased internal resistances with higher solution conductivities and lower salinity ratios. Power densities using $\mathrm{NH}_{4} \mathrm{HCO}_{3}$ solutions were slightly lower on the basis of identical molar concentrations, but similar on the basis of matched solution conductivities.
\end{abstract}




\section{Introduction}

The development of novel technologies for carbon-neutral and renewable energy generation has become increasingly important to avoid further climate change due to the release of $\mathrm{CO}_{2}$ into the atmosphere from fossil fuels [1, 2]. Salinity gradient energy, released when river water and seawater mix, could provide a large and renewable resource for clean energy production. The theoretical energy of mixing $1 \mathrm{~m}^{3}$ of river water with a large amount of seawater is about $2.5 \mathrm{MJ}$, equivalent to the energy released when water flows over a dam $250 \mathrm{~m}$ high $[3,4]$. The possible power production from globally estuarial salinity gradients, estimated to be 1.4-2.6 TW, could potentially generate electricity for over half a billion people [5-7].

Several technologies have been proposed to capture salinity gradient energy, including pressure-retarded osmosis (PRO) [8], reverse electrodialysis (RED) [9], capacitive mixing (CapMix) [10, 11], and hydrogel expansion (HEx) [12]. Each technology uses a uniquely different approach for energy conversion, but one main advantage of RED is that it can be used for continuous and direct electrical current generation from a single reactor. The RED process is based on using a stack of alternating cation (CEMs) and anion exchange membranes (AEMs) [13-15]. When solutions with salinities similar to those of seawater and river water flow through channels separated by CEMs and AEMs, a voltage of approximately 0.1 to $0.2 \mathrm{~V}$ is generated across each membrane pair due to the ion flux driven by the differences in salt concentrations [16, 17]. Cations are driven from high concentration (HC) to low concentration (LC) channels through CEMs, while anions are transferred from HC to LC compartments through AEMs. The overall potential can be raised by increasing the number of membranes $[18,19]$. The ionic flux in the stack is converted into electrical current through oxidation-reduction reactions on the end electrodes, such as water splitting on the anode and hydrogen evolution on the cathodes [20, 21]. 
Most studies on $\mathrm{RED}$ have used $\mathrm{NaCl}$ solutions at concentrations that mimic those of naturally occurring river water and seawater $[9,14,16]$, and therefore there are only a few studies on the effect of variable salt concentrations on power production in RED systems in narrow ranges of 0.5-1.8 $\mathrm{M}$ for $\mathrm{HC}$ and 0-0.15 $\mathrm{M}$ for $\mathrm{LC}$ solutions [22, 23]. However, engineered salinity gradients can be created using different salts, enabling a range of salt concentrations to be used. For example, it was recently demonstrated that power could be generated with RED using thermolytic salts, such as ammonium bicarbonate $\left(\mathrm{NH}_{4} \mathrm{HCO}_{3}, \mathrm{AmB}\right)$, that can be regenerated using waste heat [23-25]. AmB has a low temperature decomposition point, which makes it an excellent chemical for creating salinity gradients from waste heat. At low temperature $\left(40-60{ }^{\circ} \mathrm{C}\right)$, LC solution can be regenerated due to $\mathrm{AmB}$ decomposition to $\mathrm{CO}_{2}$ and $\mathrm{NH}_{4}$ gases, and $\mathrm{HC}$ solution can be obtained by dissolving $\mathrm{CO}_{2}$ and $\mathrm{NH}_{4}$ gases into $\mathrm{HC}$ effluent $[23,24]$. Approximately one-third of the energy consumed at industrial sites is lost as waste heat, and worldwide about $9400 \mathrm{TWh}$ of thermal energy could be annually recaptured for useful work production $[25,26]$. The use of closed-loop ammonia bicarbonate RED systems could enable capture of this waste heat directly as electricity $[23,27]$.

The impact of salt concentration was examined here for the purpose of using $\mathrm{AmB}$ as a method for converting waste heat into electricity using RED. Changes in solution concentrations and salinity ratios between the LC and HC chambers affect the energy input into the RED stack, as well as solution resistances and diffusion boundary layer resistances [28-30]. Additionally, membrane properties such as permselectivity and resistance are also affected by the solution concentration $[25,31]$. Thus, it is important to know how the HC and LC solutions concentration influence the power output and energy recovery of RED processes. While both $\mathrm{NaCl}$ and $\mathrm{AmB}$ have been examined separately, there have been no direct comparisons of these two different 
salts in the same RED stack. In this study, $\mathrm{NaCl}$ solutions were initially used in tests on variable salt concentrations with a commercially available RED stack to allow comparison of the results with many previous tests using fixed $\mathrm{NaCl}$ concentrations. The $\mathrm{HC}$ solution concentrations were selected to range from $0.6 \mathrm{M}$ to saturation, and the LC solution concentrations were varied from $\sim 0 \mathrm{M}$ (deionized water) to $3 \mathrm{M}$. Once the optimum conditions were identified, the performance of the RED stack was examined using AmB on the basis of either the same molar concentrations or the same solution conductivities as the $\mathrm{NaCl}$ solutions.

\section{Materials and methods}

\subsection{Reverse electrodialysis stack}

A commercially available, 10-cell-pair electrodialysis stack was used in all tests (PCCell GmbH, ED 64002-020, Heusweiler Germany). Both electrodes were titanium mesh coated with platinum and iridium (Ti/Pt-Ir), with a projected area of $64 \mathrm{~cm}^{2}(8 \mathrm{~cm} \times 8 \mathrm{~cm})$. The membrane stack was assembled with 11 standard CEMs (PC-SK) and 10 standard AEMs (PC-SA) supplied by the manufacturer, each with an active membrane area of $64 \mathrm{~cm}^{2}(8 \mathrm{~cm} \times 8 \mathrm{~cm})$, for a total active membrane area of $0.13 \mathrm{~m}^{2}$. The thickness of spacers between the membranes was $0.5 \mathrm{~mm}$. Three Masterflex® L/S pumps were separately used to pump HC, LC, and electrolyte solutions through the RED cell. A fixed concentration of $\mathrm{NaCl}(35 \mathrm{~g} / \mathrm{L}, 1 \mathrm{~L})$ was recycled through both the anode and the cathode chambers at $100 \mathrm{~mL} \mathrm{~min}^{-1}$ to avoid large $\mathrm{pH}$ changes in the anolyte or catholyte. The HC and LC solutions separately flowed through the HC and LC channels of the stack in a single pass mode at previously established optimum flow rates of $10 \mathrm{~mL} / \mathrm{min}$ for the HC solution, and $20 \mathrm{~mL} / \mathrm{min}$ for the LC solution [32]. 
Tests on salt concentration were examined by separately varying $\mathrm{NaCl}$ concentrations in $\mathrm{HC}$ and LC solutions. The $\mathrm{HC}$ solution concentration was increased from $0.6 \mathrm{M} \mathrm{NaCl}$ to saturation $(0.6,1.2,1.8,2.4,3,3.6,4.2,4.8 \mathrm{M}$, and saturated $\mathrm{NaCl})$ with the $\mathrm{LC}$ solution fixed at $0.006 \mathrm{M}$ $\mathrm{NaCl}$. When the influence of LC solution concentration was examined, the LC solution concentration was changed from $0 \mathrm{M}$ to $3 \mathrm{M} \mathrm{NaCl}(0,0.006,0.01,0.02,0.03,0.04,0.05,0.06$, $0.08,0.1,0.12,0.14,0.15,0.2,0.5,1,2$, and $3 \mathrm{M})$ with the $\mathrm{HC}$ solution concentration set at 3.6 $\mathrm{M} \mathrm{NaCl}$. The impact of the type of salts was examined using $\mathrm{NH}_{4} \mathrm{HCO}_{3}$ solutions on the basis of two different conditions: by matching the molar concentrations to those of $\mathrm{NaCl}$, with a $0.6 \mathrm{M}$ HC solution and a $0.006 \mathrm{M} \mathrm{LC}$ solution $(\mathrm{HC} 0.6 \mathrm{M} / \mathrm{LC} 0.006 \mathrm{M})$, or $1.5 \mathrm{M} \mathrm{HC}$ and $0.015 \mathrm{M} \mathrm{LC}$ solutions $(\mathrm{HC} 1.5 \mathrm{M} / \mathrm{LC} 0.015 \mathrm{M})$; or by matching the solution conductivities to those of $\mathrm{NaCl}$ with different molar concentrations (HC54 mS cm${ }^{-1} / \mathrm{LC} 0.72 \mathrm{mS} \mathrm{cm}^{-1}$, or $\mathrm{HC} 95 \mathrm{mS} \mathrm{cm} / \mathrm{LC} 1.62 \mathrm{mS}$ $\left.\mathrm{cm}^{-1}\right)$.

Four digital pressure gauges (DG25, Ashcroft Inc., Stratford, CT) were installed at the inlets and outlets of the HC and LC channels to monitor pressure changes. Two pressure regulators (Hoffman open jaw screw compressor clamp, Humboldt Scientific Inc., Raleigh, NC) were added at the outlets of the $\mathrm{HC}$ and $\mathrm{LC}$ channels to adjust and match the average pressures in $\mathrm{HC}$ and LC chambers of the RED cells to avoid membrane damage from pressure differences.

\subsection{Performance tests}

The electrochemical performance of the RED stack, in terms of open circuit voltage, maximum power density, and maximum current, was obtained from polarization tests using a potentiostat (model 1470E, Solatron Analytical, Hampshire, England). Current was scanned from 0 to the maximum current (when the voltage of the membrane stack became reversed) at a rate of 
$0.2 \mathrm{~mA} / \mathrm{s} . \mathrm{Ag} / \mathrm{AgCl}$ reference electrodes (BASi, West Lafayette, IN) were placed horizontally on either side of the membrane stack in the anolyte and catholyte through stoppers to record the stack voltage during each sweep. At least three polarization curves were obtained for each set condition. The open circuit voltage was determined from the vertical axis intercept of the polarization curves, and the maximum current was obtained from the horizontal axis intercept in the polarization curves. The power density of the membrane stack, which excluded electrode overpotentials, was calculated as [27]:

$P_{\text {stack }}=\frac{U_{\text {stack }} \times I_{\text {stack }}}{A_{\text {mem }}}$

where $P_{\text {stack }}$ is the power density of the membrane stack ( $\mathrm{W} / \mathrm{m}^{2}$ membrane), $U_{\text {stack }}$ is the voltage of the membrane stack $(\mathrm{V}), I_{\text {stack }}$ is the scanned current (A), and $A_{\text {mem }}$ is the total active membrane area of the stack $\left(\mathrm{m}^{2}\right)$.

\subsection{Energy input and energy recovery}

Energy input to the system $\left(X^{\text {in }}\right.$, in W) changes with the HC and LC solutions concentration, which was determined from the change in the free energy due to complete mixing of the $\mathrm{HC}$ and LC solutions as [12, 33]:

$$
X^{i n}=R T \sum_{i}\left(Q_{H C} c_{i, H C}^{i n} \ln \frac{a_{i, H C}^{i n}}{a_{i, M}}+Q_{L C} c_{i, L C}^{i n} \ln \frac{a_{i, L C}^{i n}}{a_{i, M}}\right)
$$

where $R\left(8.314 \mathrm{~J} \mathrm{~mol}^{-1} \mathrm{~K}^{-1}\right)$ is the universal gas constant, $T(298 \mathrm{~K})$ the absolute temperature, $Q$ $\left(\mathrm{L} \mathrm{s}^{-1}\right)$ the flow rate of the solutions, $c(\mathrm{M})$ the molar concentration of ionic species $i$ in the solution, $a$ the activity of ionic species $i$ in the solutions obtained using OLI Analyzer Studio software (OLI Systems Inc., Cedar Knolls, NJ), and the subscripts HC, LC, and M indicates the high concentration, low concentration, and mixed solutions. 


\section{Results and discussion}

\subsection{Influence of HC solution concentration}

When $\mathrm{NaCl}$ concentration in the $\mathrm{HC}$ solution was changed from $0.6 \mathrm{M}$ to saturation with a fixed LC concentration of $0.006 \mathrm{M}$, the open circuit voltage (OCV) was constant at $1.58 \pm 0.03 \mathrm{~V}$ (Fig. 1A). The absence of an increase indicated that concentration of the HC stream was not a limiting factor in the OCV. However, both the maximum power densities (Fig. 1B) and the maximum currents (Fig. 1C) increased with $\mathrm{HC}$ concentration up to $3.6 \mathrm{M}$, and then became relatively stable above $3.6 \mathrm{M}$. These increases were mainly due to the increased salinity ratio driving increases in current. The power was also improved due to decreases in ohmic solution and non-ohmic diffusion boundary layer resistances in the $\mathrm{HC}$ channels due to the added higher salt concentrations, and decreases in these resistances in the LC channels due to the increased salt crossover from the $\mathrm{HC}$ into the LC channels [28]. A lack of further increases in power at $\mathrm{HC}$ concentrations above $3.6 \mathrm{M}$ was likely limited by ionic transport capability in the ion exchange membranes. It has been demonstrated that high solution concentrations suppress the Donnan exclusion capacity of the ion exchange membranes, severely reducing the permselectivity and diminishing energy conversion efficiency in a RED stack [25, 35]. Increase of the charge groups in the membranes may improve the ion exchange capacity, but other factors (e.g, electrical resistance, swelling degree, permselectivity, and mechanical strength) should also be taken into account $[13,36,37]$. 

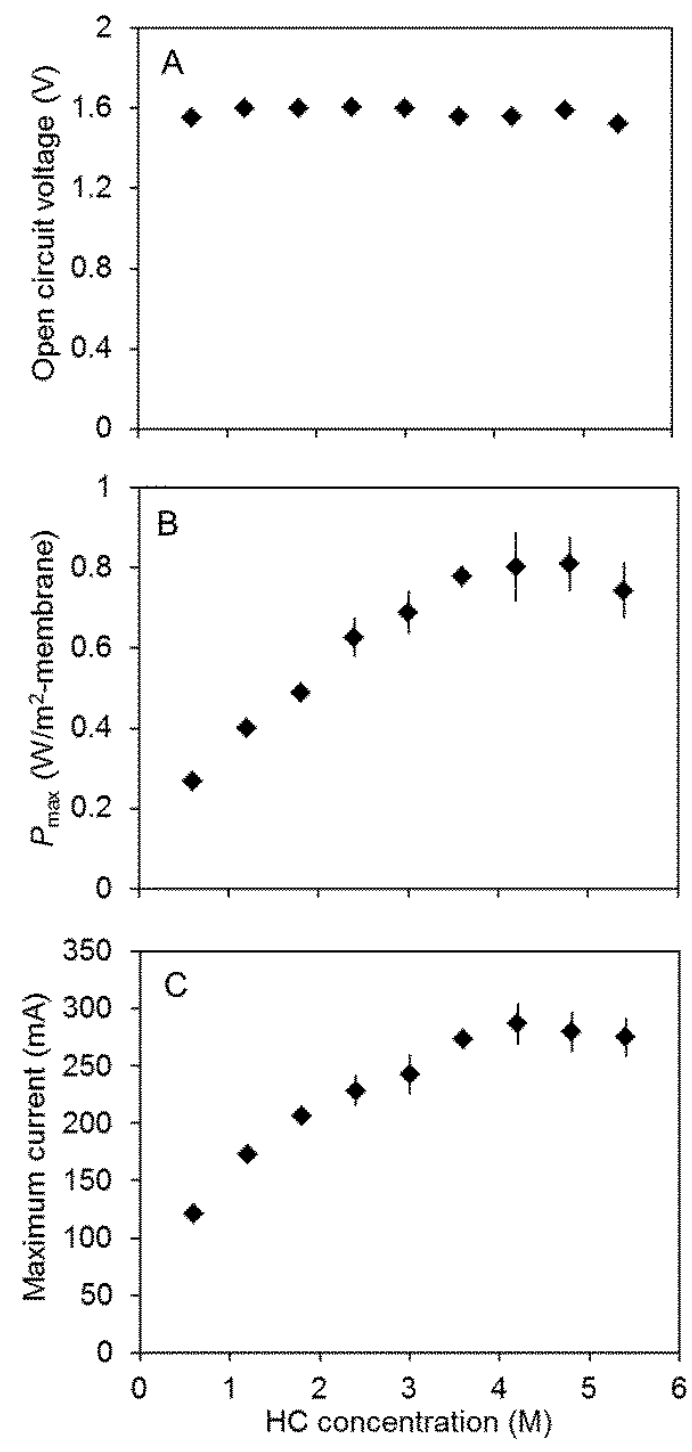

Fig. 1. (A) Open circuit voltage, (B) maximum power density, and (C) maximum current of the RED stack when HC solution concentration increased from $0.6 \mathrm{M}$ to saturated $\mathrm{NaCl}$ and $\mathrm{LC}$ solution concentration was $0.006 \mathrm{M} \mathrm{NaCl}$.

The change of HC solution concentration had no impact on the hydrodynamic power loss (pumping energy) as demonstrated by similar pressure drops in the HC and LC channels (Fig. 2A). The energy input increased almost linearly with HC concentration due to the higher salinity ratios (Fig. 2B). However, energy recovery decreased inversely with the $\mathrm{HC}$ concentration due to inefficient capture of mixing energy, and limitations in ion transport through the membrane (Fig. 2B). In order to obtain a maximum energy output and relatively higher energy recovery, the 
optimum HC solution concentration was considered here to be $\sim 3.6 \mathrm{M}$. Under this condition, the open circuit voltage was $1.56 \pm 0.01 \mathrm{~V}$, the maximum power density was $0.78 \pm 0.03 \mathrm{~W} / \mathrm{m}^{2}$ membrane (total area), the maximum current was $274 \pm 8 \mathrm{~mA}$, and the overall energy recovery was $3.0 \%$. The energy recovery was low due to the use of a single pass of the solutions through the membranes, but it could be enhanced by passing the effluents through additional units or recycling through the same unit $[33,38]$.

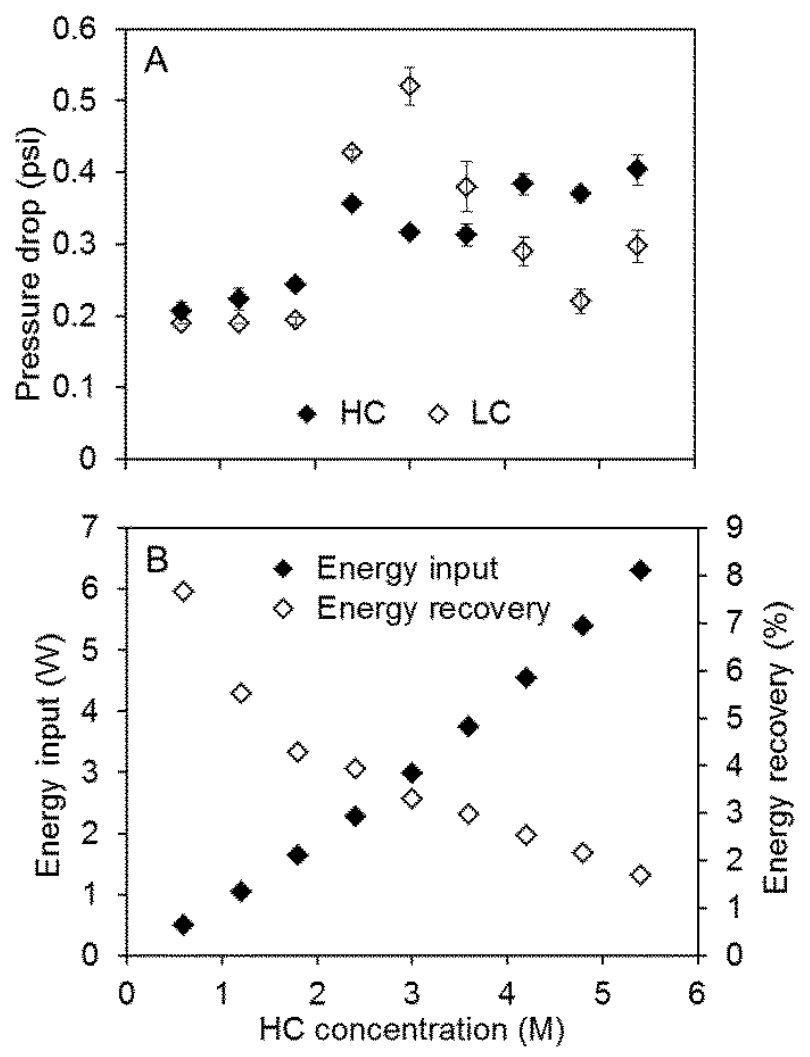

Fig. 2. (A) Pressure drops of HC and LC channels and (B) energy input and energy recovery of the RED stack when $\mathrm{HC}$ solution concentration increased from $0.6 \mathrm{M}$ to saturated $\mathrm{NaCl}$ and $\mathrm{LC}$ solution concentration was $0.006 \mathrm{M} \mathrm{NaCl}$. 


\subsection{Influence of $L C$ solution concentration}

An increase of $\mathrm{NaCl}$ concentration in the $\mathrm{LC}$ solution from 0 to $3 \mathrm{M} \mathrm{NaCl}$, with a fixed $\mathrm{HC}$ solution concentration of $3.6 \mathrm{M}$, consistently decreased the OCV (Fig. 3A and 3B) due to the lower salinity ratio (energy input). However, the maximum power densities and maximum currents were nearly constant in the low LC solution concentration range of 0 to $0.14 \mathrm{M}$ (Fig. 3D and 3F), and they only rapidly decreased at LC solution concentrations above $0.14 \mathrm{M}$ (Fig. 3C and 3E). The stable power output below $0.14 \mathrm{M}$ was likely a result of the trade-off between the reduction of ohmic solution resistance achieved by using an LC solution with a higher concentration of salt (greater ion conductivity), and the decrease in the salinity ratio which would reduce the driving force for power generation. At LC solution concentrations lower than $0.14 \mathrm{M}$, changes in these two properties were relatively balanced, resulting in little change in power production with low LC solution concentrations. However, at LC solution concentrations larger than $0.14 \mathrm{M}$, the influence of solution resistance on power generation was less important, and the reduction of the salinity ratio $(<25)$ was the main factor affecting power production. Thus, the power output greatly declined with LC solution concentrations $>0.14 \mathrm{M}$. 

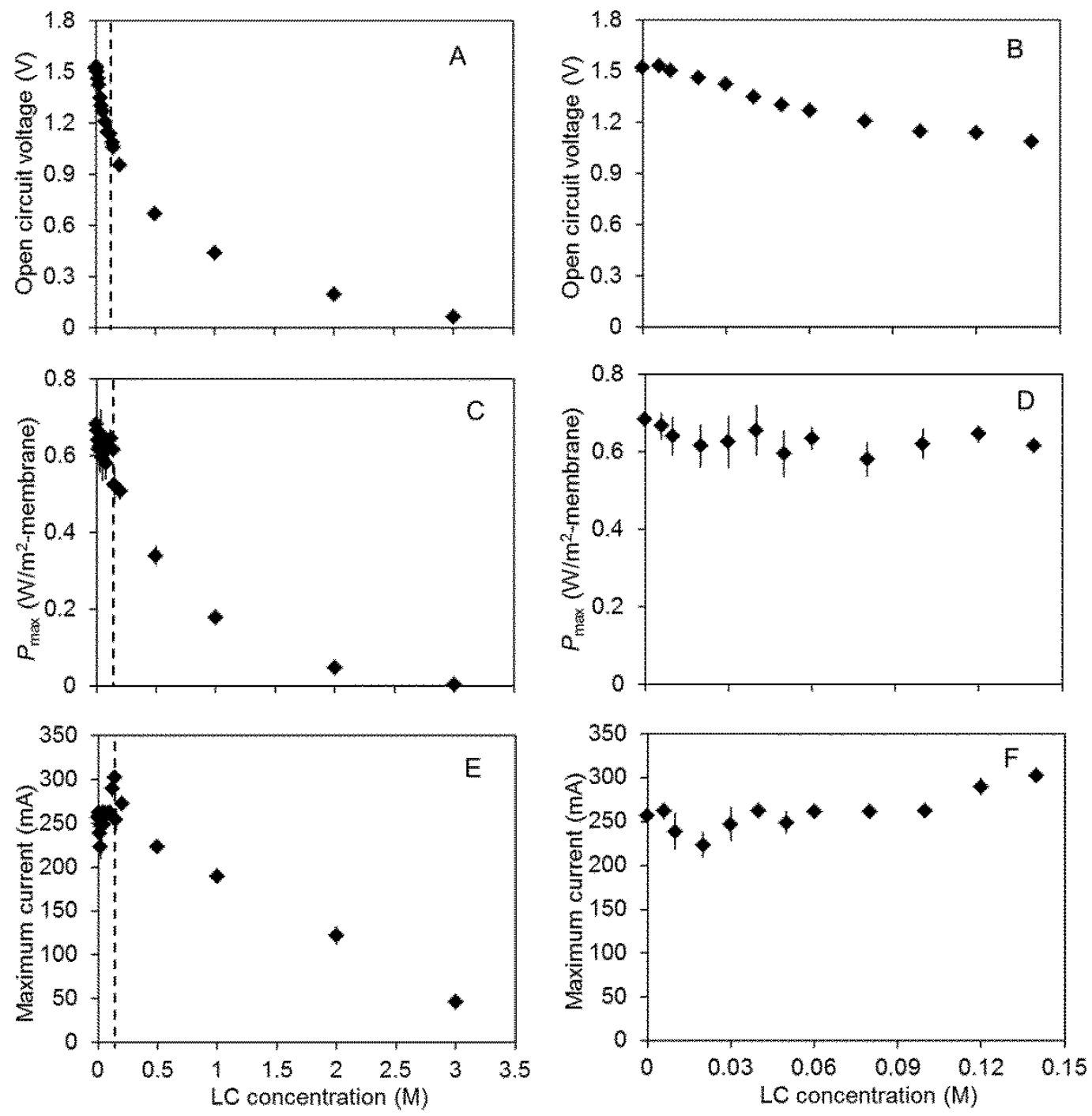

Fig. 3. Open circuit voltage for a whole range (A) and a narrow range (B), maximum power density for a whole range (C) and a narrow range (D), and maximum current for a whole range (E) and a narrow range $(\mathrm{F})$ of the RED stack when LC solution concentration increased from 0 $\mathrm{M}$ to $3 \mathrm{M} \mathrm{NaCl}$ and $\mathrm{HC}$ solution concentration was $3.6 \mathrm{M} \mathrm{NaCl}$.

The pressure drops through HC and LC channels were also quite similar over the range of LC solution concentrations (Fig. 4A and 4B), which indicated that the hydrodynamic power losses (pumping energy) were unaffected by the LC concentration. The energy input almost linearly 

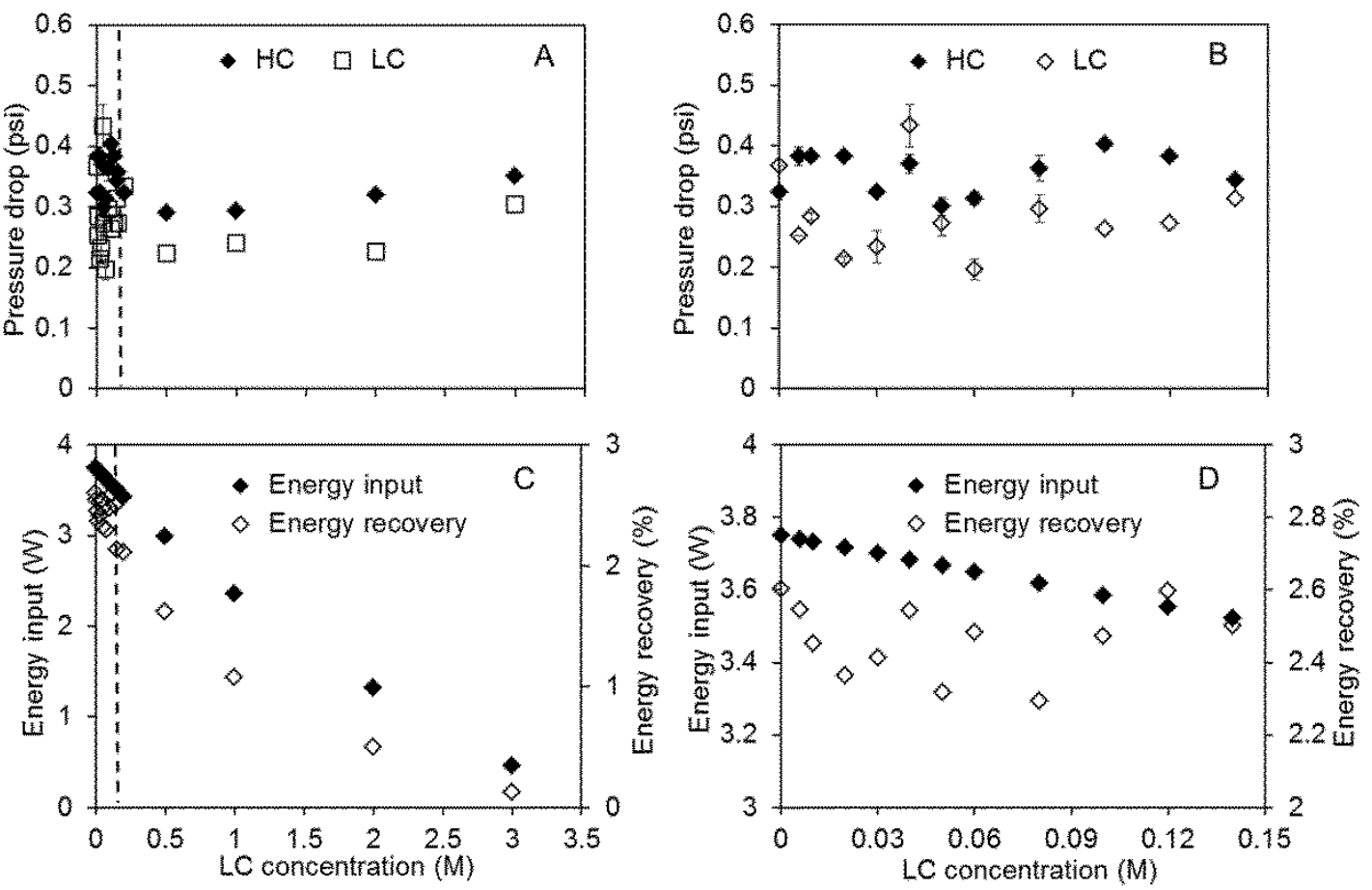
Fig. 4. Pressure drops of $\mathrm{HC}$ and $\mathrm{LC}$ channels for a whole range (A) and a narrow range (B), and energy input and energy recovery for a whole range (C) and a narrow range (D) of the RED stack when LC solution concentration increased from $0 \mathrm{M}$ to $3 \mathrm{M} \mathrm{NaCl}$ and $\mathrm{HC}$ solution concentration was $3.6 \mathrm{M} \mathrm{NaCl}$.

The maximum power density of $0.62 \mathrm{~W} / \mathrm{m} 2$-membrane here with $\mathrm{HC}$ of $3.6 \mathrm{M}$ and LC of $0.14 \mathrm{M}$ was within the range of previous results of 0.4 to $1.4 \mathrm{~W} / \mathrm{m}^{2}$-membrane, although within the lower range of those power densities $[14,18,19,36]$. Differences in the studied conditions could all be a factor, including the relatively low flow rates ( $\mathrm{HC}$ of $10 \mathrm{~mL} / \mathrm{min}$, linear velocity of $2.5 \mathrm{~cm} / \mathrm{min}$, LC of $20 \mathrm{~mL} / \mathrm{min}$, linear velocity of $5 \mathrm{~cm} / \mathrm{min}$ ) used here to reduce pumping energy as previously reported [32], the intermembrane distance of $0.5 \mathrm{~mm}$ which could be reduced using different spacers [39], and the permselectivity of the ion exchange membranes compared to those used by others $[13,40]$. Although the optimum HC and LC solution concentrations for other RED cells at different operating conditions might not be the same as those here, the general trends of RED performances with the different $\mathrm{HC}$ and LC solution concentrations would be similar to those observed here. The most important factor is the membrane. In order to make RED application practical, the electrochemical properties of ion exchange membranes used in these systems need to be further improved, and the price of the membranes needs to be reduced.

\subsection{Comparison between $\mathrm{NaCl}$ and $\mathrm{NH}_{4} \mathrm{HCO}_{3}$ solutions}

Based on the above results using $\mathrm{NaCl}$, the performance of the RED stack was examined using $\mathrm{NH}_{4} \mathrm{HCO}_{3}$ at two different ratios of salt concentrations. The first comparison was made at $\mathrm{NH}_{4} \mathrm{HCO}_{3}$ molar concentrations that matched the $\mathrm{NaCl}$ concentrations used to represent typical river water and seawater $(\mathrm{HC} 0.6 \mathrm{M} / \mathrm{LC} 0.006 \mathrm{M})$. The second comparison was made at a very high molar concentration based on upper limits for the solubility of $\mathrm{NH}_{4} \mathrm{HCO}_{3}(\mathrm{HC} 1.5 \mathrm{M} / \mathrm{LC} 0.015 \mathrm{M})$. 
When the $\mathrm{NH}_{4} \mathrm{HCO}_{3}$ and $\mathrm{NaCl}$ solutions are used at identical molar concentrations, the ionic conductivities of the solutions are different due to the different ion activities (Table 1). Therefore, the concentrations of the $\mathrm{NH}_{4} \mathrm{HCO}_{3}$ solutions were increased using additional salt to match the conductivities of the $\mathrm{NaCl}$ solutions with molar concentrations of $0.6 \mathrm{M}$ for $\mathrm{HC}$ and $0.006 \mathrm{M}$ for $\mathrm{LC}$, which was indicated as $\mathrm{HC} 54 \mathrm{mS} \mathrm{cm} / \mathrm{LC} 0.72 \mathrm{mS} \mathrm{cm}^{-1}$. The concentrations of the $\mathrm{NaCl}$ solutions were decreased to match the conductivities of the $\mathrm{NH}_{4} \mathrm{HCO}_{3}$ solutions at molar concentrations of $1.5 \mathrm{M}$ for $\mathrm{HC}$ and $0.015 \mathrm{M}$ for $\mathrm{LC}$, which was indicated as $\mathrm{HC} 95 \mathrm{mS} \mathrm{cm}^{-}$ ${ }^{1} / \mathrm{LC} 1.62 \mathrm{mS} \mathrm{cm}^{-1}$ (Table 1).

Table 1. Concentration $(C$, in $\mathrm{M})$ and conductivity $\left(S\right.$, in $\left.\mathrm{mS} \mathrm{cm}^{-1}\right)$ of $\mathrm{NaCl}$ and $\mathrm{NH}_{4} \mathrm{HCO}_{3}$

\begin{tabular}{|c|c|c|c|c|c|c|c|}
\hline \multicolumn{4}{|c|}{$\mathrm{NaCl}$} & \multicolumn{3}{c|}{$\mathrm{NH}_{4} \mathrm{HCO}_{3}(\mathrm{AmB})$} \\
\hline \multicolumn{2}{|c|}{$\mathrm{HC}$} & \multicolumn{2}{|c|}{$\mathrm{LC}$} & \multicolumn{2}{c|}{$\mathrm{HC}$} \\
\hline$C / \mathrm{M}$ & $S / \mathrm{mS} \mathrm{cm}^{-1}$ & $C / \mathrm{M}$ & $S / \mathrm{mS} \mathrm{cm}^{-1}$ & $C / \mathrm{M}$ & $\mathrm{S} / \mathrm{mS} \mathrm{cm}^{-1}$ & $C / \mathrm{M}$ & $S / \mathrm{mS} \mathrm{cm}^{-1}$ \\
\hline 0.6 & 54 & 0.006 & 0.72 & 0.6 & 45 & 0.006 & 0.80 \\
\hline 1.5 & 119 & 0.015 & 1.85 & 1.5 & 95 & 0.015 & 1.62 \\
\hline 1.13 & 95 & 0.013 & 1.62 & 0.74 & 54 & 0.005 & 0.72 \\
\hline
\end{tabular}

When the RED stack performance was examined on the basis of matching the molar concentrations of the $\mathrm{NH}_{4} \mathrm{HCO}_{3}$ to $\mathrm{NaCl}$ solutions, power production was reduced (Fig. 5A). Part of this reduction in power was due to the lower permselectivities of $\mathrm{NH}_{4} \mathrm{HCO}_{3}$ in these membranes compared to $\mathrm{NaCl}$ [40]. However, the main reason was the different solution conductivities. When the conductivities of the $\mathrm{NH}_{4} \mathrm{HCO}_{3}$ were adjusted to match those of the $\mathrm{NaCl}$ solutions, the maximum power densities of the RED stack was similar for both $\mathrm{NaCl}$ and $\mathrm{NH}_{4} \mathrm{HCO}_{3}$ solutions (Fig. 5B). 

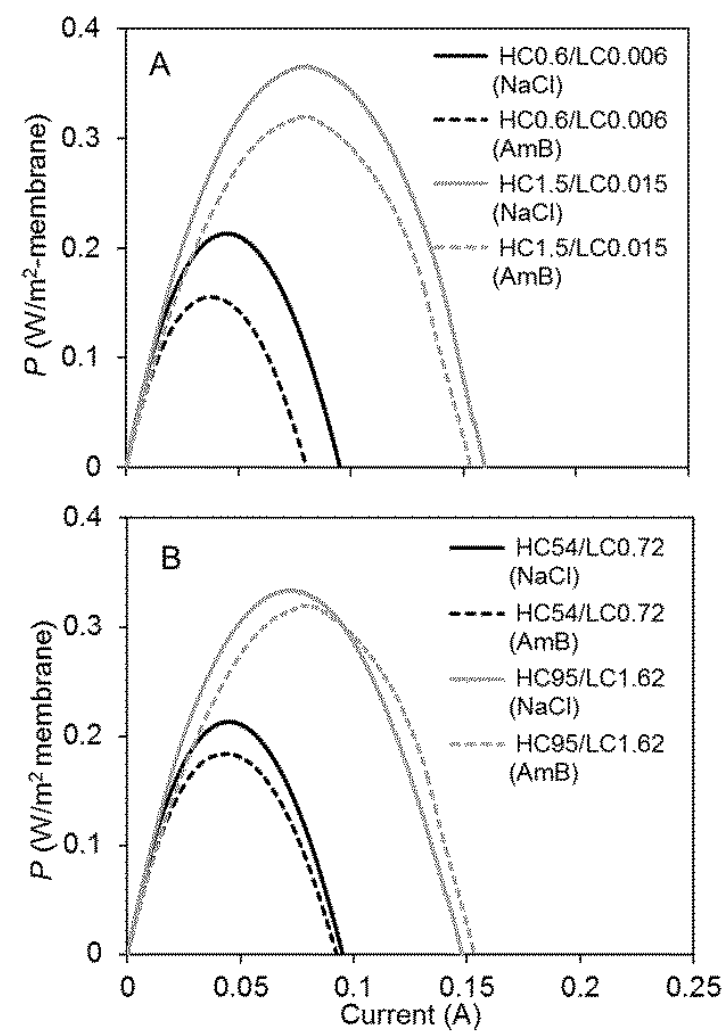

Fig. 5. Polarization curves of the RED stack with $\mathrm{NaCl}$ and $\mathrm{NH}_{4} \mathrm{HCO}_{3}$ solutions (A) at the same molar concentrations (HC0.6M/LC0.006M or HC1.5M/LC0.015M), or (B) at the same conductivities (HC54 mS cm${ }^{-1} / \mathrm{LC} 0.72 \mathrm{mS} \mathrm{cm}^{-1}$ or $\mathrm{HC} 95 \mathrm{mS} \mathrm{cm} \mathrm{CL}^{-1} / \mathrm{LC} 1.62 \mathrm{mS} \mathrm{cm}^{-1}$ ).

The energy input was higher using $\mathrm{NaCl}$ solutions than $\mathrm{NH}_{4} \mathrm{HCO}_{3}$ on the basis of the same molar concentrations due to the higher activities of $\mathrm{Na}^{+}$and $\mathrm{Cl}^{-}$ions, especially for the high concentration pair (HC1.5M/LC0.015M) (Fig. 6), in agreement with the better performance of the $\mathrm{RED}$ stack with $\mathrm{NaCl}$ solutions. The energy recovery was also larger for $\mathrm{NaCl}$ when the two solutions were compared at the same molar concentrations at the lower salt concentrations (HC0.6M/LC0.006M), but it was smaller at the higher salt concentrations (HC1.5M/LC0.015M) (Fig. 6). The larger reduction in energy recovery at the higher $\mathrm{NaCl}$ concentrations reflected greater losses of mixing energy, which could have resulted from easier $\mathrm{Na}^{+}$and $\mathrm{Cl}^{-}$ions 
transport (permeability) through the membranes under these conditions. The energy inputs were similar when solutions conductivities were matched (Fig. 6), but the energy recovery was larger for $\mathrm{NaCl}$ solution for the low conductivity conditions pair $\left(\mathrm{HC} 54 \mathrm{mS} \mathrm{cm} / \mathrm{LC} 0.72 \mathrm{mS} \mathrm{cm}^{-1}\right.$ ), and similar for high conductivity pair (HC95 mS cm${ }^{-1} / \mathrm{LC} 1.62 \mathrm{mS} \mathrm{cm}^{-1}$ ) (Fig. 6). These results indicate that previous results for RED tests using $\mathrm{NaCl}$ solutions can be used for $\mathrm{NH}_{4} \mathrm{HCO}_{3}$ solutions, but only when the solution conductivities are matched.

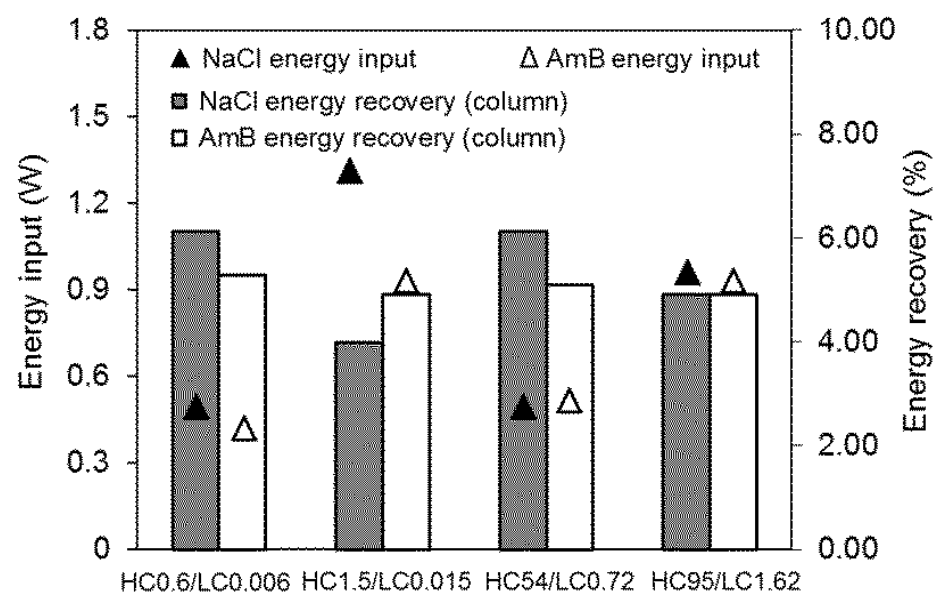

Fig. 6. Energy input and energy recovery of the RED stack with $\mathrm{NaCl}$ and $\mathrm{NH}_{4} \mathrm{HCO}_{3}$ solutions at the same molar concentrations (HC0.6M/LC0.006M or HC1.5M/LC0.015M), or at the same conductivities (HC54 mS cm$/ 1 / L C 0.72 \mathrm{mS} \mathrm{cm}^{-1}$ or $\mathrm{HC} 95 \mathrm{mS} \mathrm{cm}^{-1} / \mathrm{LC} 1.62 \mathrm{mS} \mathrm{cm}^{-1}$ ).

\section{Conclusions}

The performance of the RED stack significantly affected by the HC and LC solution concentrations. The power output of the RED stack increased with the HC solution concentration in the range of $0.6 \mathrm{M}$ to $3.6 \mathrm{M} \mathrm{NaCl}$, but it was constant above $3.6 \mathrm{M}$ as further increase in power was limited by the ion exchange capacity of membranes. The power output of the RED stack was relatively constant for $\mathrm{LC}$ solution concentrations of 0 to $0.14 \mathrm{M} \mathrm{NaCl}$ due to the trade-off between decreased salinity ratios and solution resistances, while it greatly decreased 
above $0.14 \mathrm{M}$ due to the much lower salinity ratio. The performance of the RED stack with $\mathrm{NH}_{4} \mathrm{HCO}_{3}$ salt was lower than that with $\mathrm{NaCl}$ salt at the same molar concentrations due to lower ion activities, but they were similar when the solution conductivities were matched. These results therefore indicated that previous conclusions regarding RED tests using $\mathrm{NaCl}$ solutions are suitable for $\mathrm{NH}_{4} \mathrm{HCO}_{3}$ solutions when tests are conducted at the same solution conductivities.

\section{Acknowledgments}

This research was supported by U.S. Department of Energy Cooperative Agreement DEEE0005750.

\section{References}

[1] T.J. Crowley, Causes of climate change over the past 1000 years, Science 289 (2000) 270277.

[2] J. Hansen, M. Sato, R. Ruedy, A. Lacis, V. Oinas, Global warming in the twenty-first century: An alternative scenario, P. Natl. Acad. Sci. USA 97 (2000) 9875-9880.

[3] R.E. Pattle, Production of Electric Power by Mixing Fresh and Salt Water in the Hydroelectric Pile, Nature 174 (1954) 660-660.

[4] B.E. Logan, M. Elimelech, Membrane-based processes for sustainable power generation using water, Nature 488 (2012) 313-319.

[5] G.L. Wick, W.R. Schmitt, Prospects for renewable energy from the sea, Mar. Technol. Soc. J. 11 (1977) 16-21.

[6] J.D. Isaacs, R.J. Seymour, The ocean as a power resource, Int. J. Environ. Stud. 4 (1973) 201205.

[7] N.Y. Yip, M. Elimelech, Thermodynamic and energy efficiency analysis of power generation from natural salinity gradients by pressure retarded osmosis, Environ. Sci. Technol. 46 (2012) 5230-5239.

[8] A. Achilli, A.E. Childress, Pressure retarded osmosis: From the vision of Sidney Loeb to the first prototype installation - Review, Desalination 261 (2010) 205-211.

[9] J.W. Post, H.V.M. Hamelers, C.J.N. Buisman, Energy recovery from controlled mixing salt and fresh water with a reverse electrodialysis system, Environ. Sci. Technol. 42 (2008) 57855790.

[10] D. Brogioli, Extracting renewable energy from a salinity difference using a capacitor, Phys. Rev. Lett. 103 (2009). 
[11] M.C. Hatzell, K.B. Hatzell, B.E. Logan, Using flow electrodes in multiple reactors in series for continuous energy generation from capacitive mixing, Environ. Sci. Technol. Lett. 1 (2014) 474-478.

[12] X.P. Zhu, W.L. Yang, M.C. Hatzell, B.E. Logan, Energy recovery from solutions with different salinities based on swelling and shrinking of hydrogels, Environ. Sci. Technol. 48 (2014) 7157-7163.

[13] E. Guler, R. Elizen, D.A. Vermaas, M. Saakes, K. Nijmeijer, Performance-determining membrane properties in reverse electrodialysis, J. Membr. Sci. 446 (2013) 266-276.

[14] J. Veerman, M. Saakes, S.J. Metz, G.J. Harmsen, Electrical power from sea and river water by reverse electrodialysis: a first step from the laboratory to a real power plant, Environ. Sci. Technol. 44 (2010) 9207-9212.

[15] J. Veerman, R.M. de Jong, M. Saakes, S.J. Metz, G.J. Harmsen, Reverse electrodialysis: Comparison of six commercial membrane pairs on the thermodynamic efficiency and power density, J. Membr. Sci. 343 (2009) 7-15.

[16] G.Z. Ramon, B.J. Feinberg, E.M.V. Hoek, Membrane-based production of salinity-gradient power, Energ. Environ. Sci. 4 (2011) 4423-4434.

[17] D.A. Vermaas, E. Guler, M. Saakes, K. Nijmeijer, Theoretical power density from salinity gradients using reverse electrodialysis, Energy Procedia 20 (2012) 170-184.

[18] J. Veerman, M. Saakes, S.J. Metz, G.J. Harmsen, Reverse electrodialysis: Performance of a stack with 50 cells on the mixing of sea and river water, J. Membr. Sci. 327 (2009) 136-144.

[19] P. Dlugolecki, A. Gambier, K. Nijmeijer, M. Wessling, Practical potential of reverse electrodialysis as process for sustainable energy generation, Environ. Sci. Technol. 43 (2009) 6888-6894.

[20] J. Veerman, M. Saakes, S.J. Metz, G.J. Harmsen, Reverse electrodialysis: evaluation of suitable electrode systems, J. Appl. Electrochem. 40 (2010) 1461-1474.

[21] O.S. Burheim, F. Seland, J.G. Pharoah, S. Kjelstrup, Improved electrode systems for reverse electro-dialysis and electro-dialysis, Desalination 285 (2012) 147-152.

[22] X. Luo, X.X. Cao, Y.H. Mo, K. Xiao, X.Y. Zhang, P. Liang, X. Huang, Power generation by coupling reverse electrodialysis and ammonium bicarbonate: Implication for recovery of waste heat, Electrochem. Commun. 19 (2012) 25-28.

[23] R.D. Cusick, Y. Kim, B.E. Logan, Energy capture from thermolytic solutions in microbial reverse-electrodialysis Cells, Science 335 (2012) 1474-1477.

[24] R.L. McGinnis, J.R. McCutcheon, M. Elimelech, A novel ammonia-carbon dioxide osmotic heat engine for power generation, J. Membr. Sci. 305 (2007) 13-19.

[25] N.Y. Yip, M. Elimelech, Comparison of energy efficiency and power density in pressure retarded osmosis and reverse electrodialysis, Environ. Sci. Technol. 48 (2014) 11002-11012.

[26] S. Lin, N.Y. Yip, T.Y. Cath, C.O. Osuji, M. Elimelech, Hybrid pressure retarded osmosis membrane distillation system for power generation from low-grade heat: Thermodynamic analysis and energy efficiency Environ. Sci. Technol. 48 (2014) 5306-5313.

[27] M.C. Hatzell, I. Ivanov, R.D. Cusick, X.P. Zhu, B.E. Logan, Comparison of hydrogen production and electrical power generation for energy capture in closed-loop ammonium bicarbonate reverse electrodialysis systems, Phys. Chem. Chem. Phys. 16 (2014) 1632-1638. [28] P. Dlugolecki, P. Ogonowski, S.J. Metz, M. Saakes, K. Nijmeijer, M. Wessling, On the resistances of membrane, diffusion boundary layer and double layer in ion exchange membrane transport, J. Membr. Sci. 349 (2010) 369-379. 
[29] S. Pawlowski, P. Sistat, J.G. Crespo, S. Velizarov, Mass transfer in reverse electrodialysis: Flow entrance effects and diffusion boundary layer thickness, J. Membr. Sci. 471 (2014) 7283.

[30] L. Gurreri, A. Tamburini, A. Cipollina, G. Micale, M. Ciofalo, CFD prediction of concentration polarization phenomena in spacer-filled channels for reverse electrodialysis, J. Membr. Sci. 468 (2014) 133-148.

[31] G.M. Geise, A.J. Curtis, M.C. Hatzell, M.A. Hickner, B.E. Logan, Salt concentration differences alter membrane resistance in reverse electrodialysis stacks, Environ. Sci. Technol. Lett. 1 (2014) 36-39.

[32] X.P. Zhu, W.H. He, B.E. Logan, Reducing pumping energy by using different flow rates of high and low concentration solutions in reverse electrodialysis cells, J. Membr. Sci. 486 (2015) 215-221.

[33] J.Y. Nam, R.D. Cusick, Y. Kim, B.E. Logan, Hydrogen generation in microbial reverseelectrodialysis electrolysis cells using a heat-regenerated salt solution, Environ. Sci. Technol. 46 (2012) 5240-5246.

[34] N.Y. Yip, D.A. Vermaas, K. Nijmeijer, M. Elimelech, Thermodynamic, energy efficiency, and power density analysis of reverse electrodialysis power generation with natural salinity gradients, Environ. Sci. Technol. 48 (2014) 4925-4936.

[35] A. Daniilidis, D.A. Vermaas, R. Herber, K. Nijmeijer, Experimentally obtainable energy from mixing river water, seawater or brines with reverse electrodialysis, Renewable Energy 64 (2014) 123-131.

[36] J.G. Hong, Y.S. Chen, Evaluation of electrochemical properties and reverse electrodialysis performance for porous cation exchange membranes with sulfate-functionalized iron oxide, J. Membr. Sci. 473 (2015) 210-217.

[37] G.M. Geise, M.A. Hickner, B.E. Logan, Ionic resistance and permselectivity tradeoffs in anion exchange membranes, ACS Appl. Mater. Interfaces 5 (2013) 10294-10301.

[38] D.A. Vermaas, J. Veerman, N.Y. Yip, M. Elimelech, M. Saakes, K. Nijmeijer, High efficiency in energy generation from salinity gradients with reverse electrodialysis, ACS Sustainable Chem. Eng. 1 (2013) 1295-1302.

[39] D.A. Vermaas, M. Saakes, K. Nijmeijer, Doubled power density from salinity gradients at reduced intermembrane distance, Environ. Sci. Technol. 45 (2011) 7089-7095.

[40] G.M. Geise, H.J. Cassady, D.R. Paul, B.E. Logan, M.R. Hickner, Specific ion effects on membrane potential and the permselectivity of ion exchange membranes Phys. Chem. Chem. Phys. 16 (2014) 21673-21681. 
Figure-1
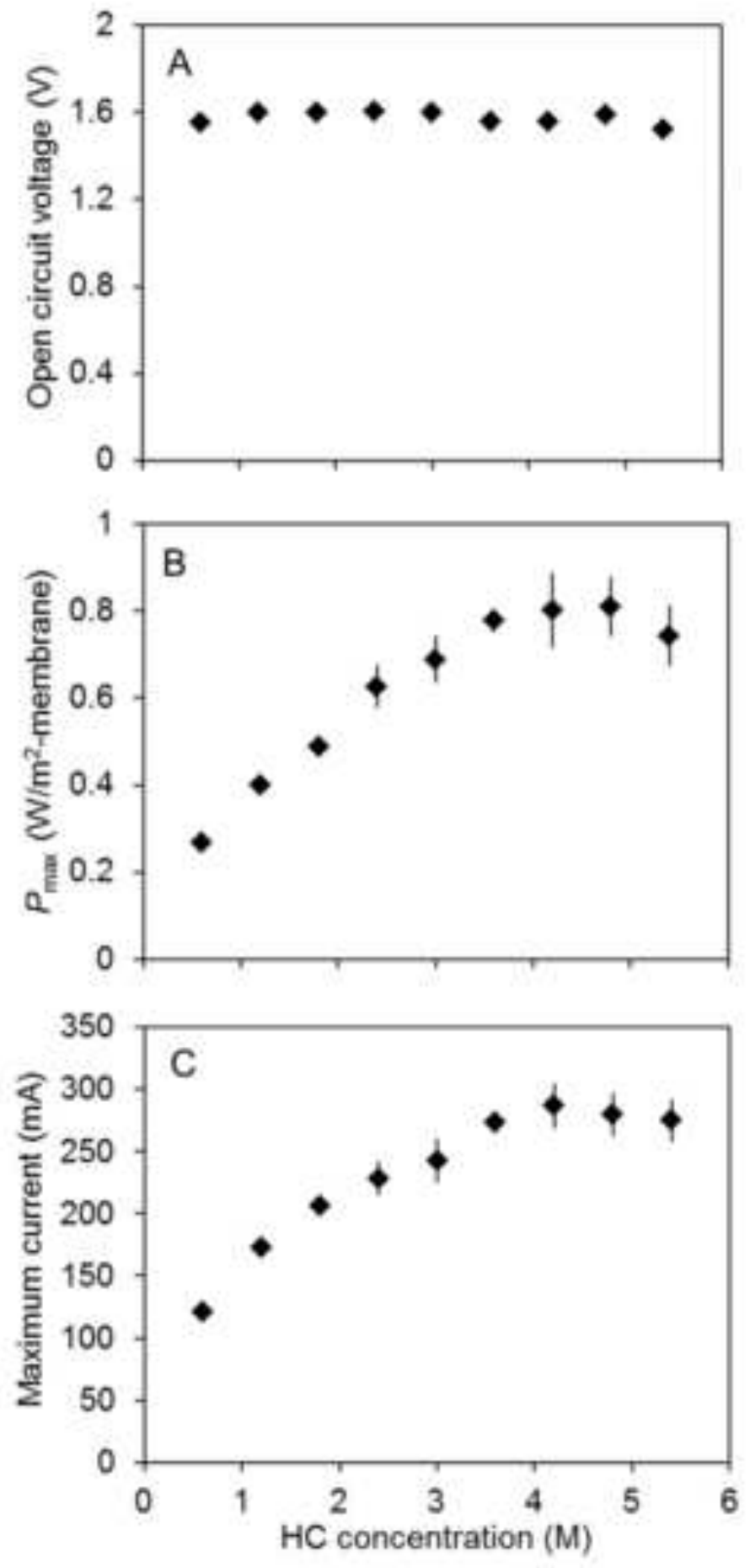

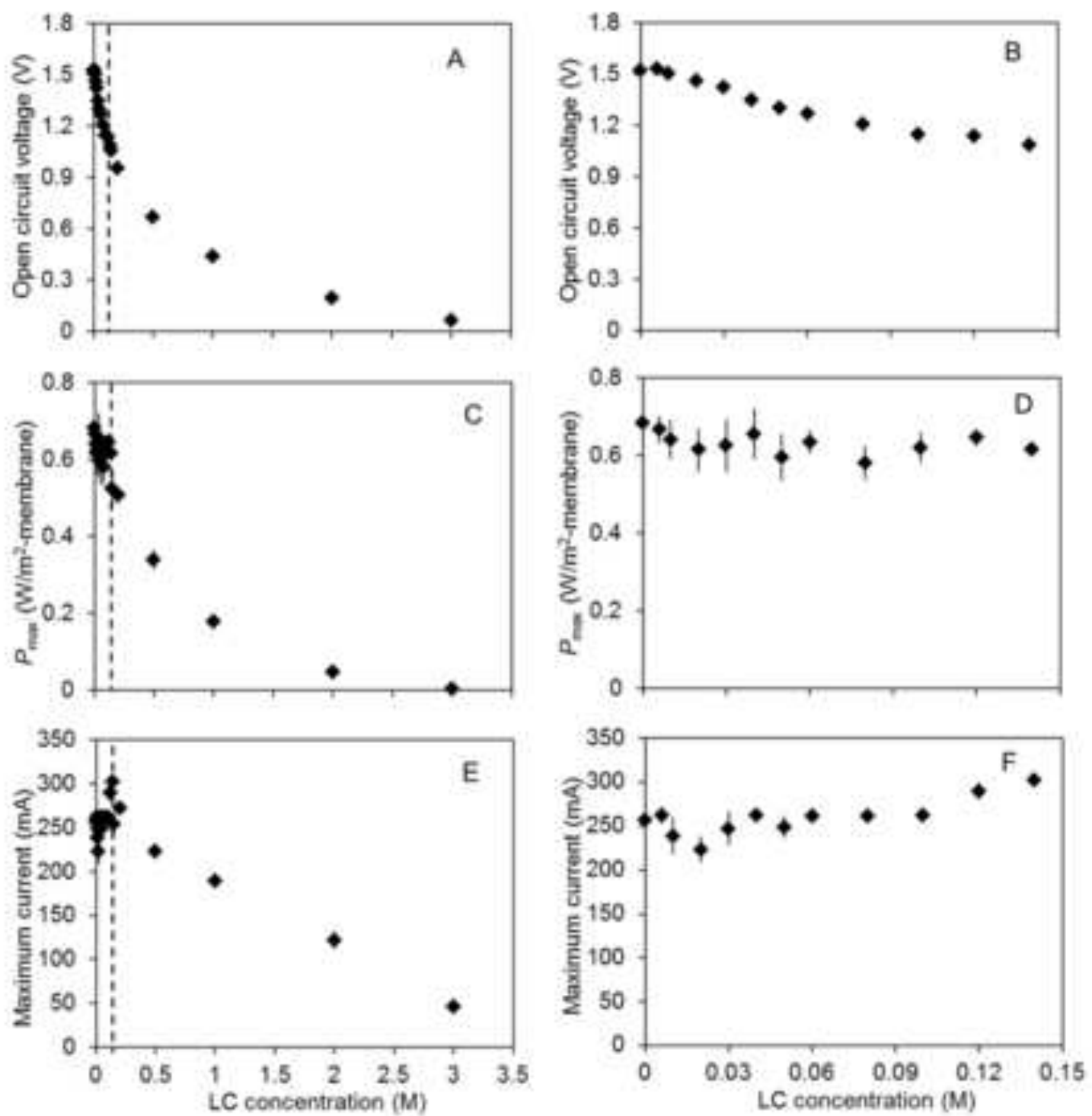
Figure-4
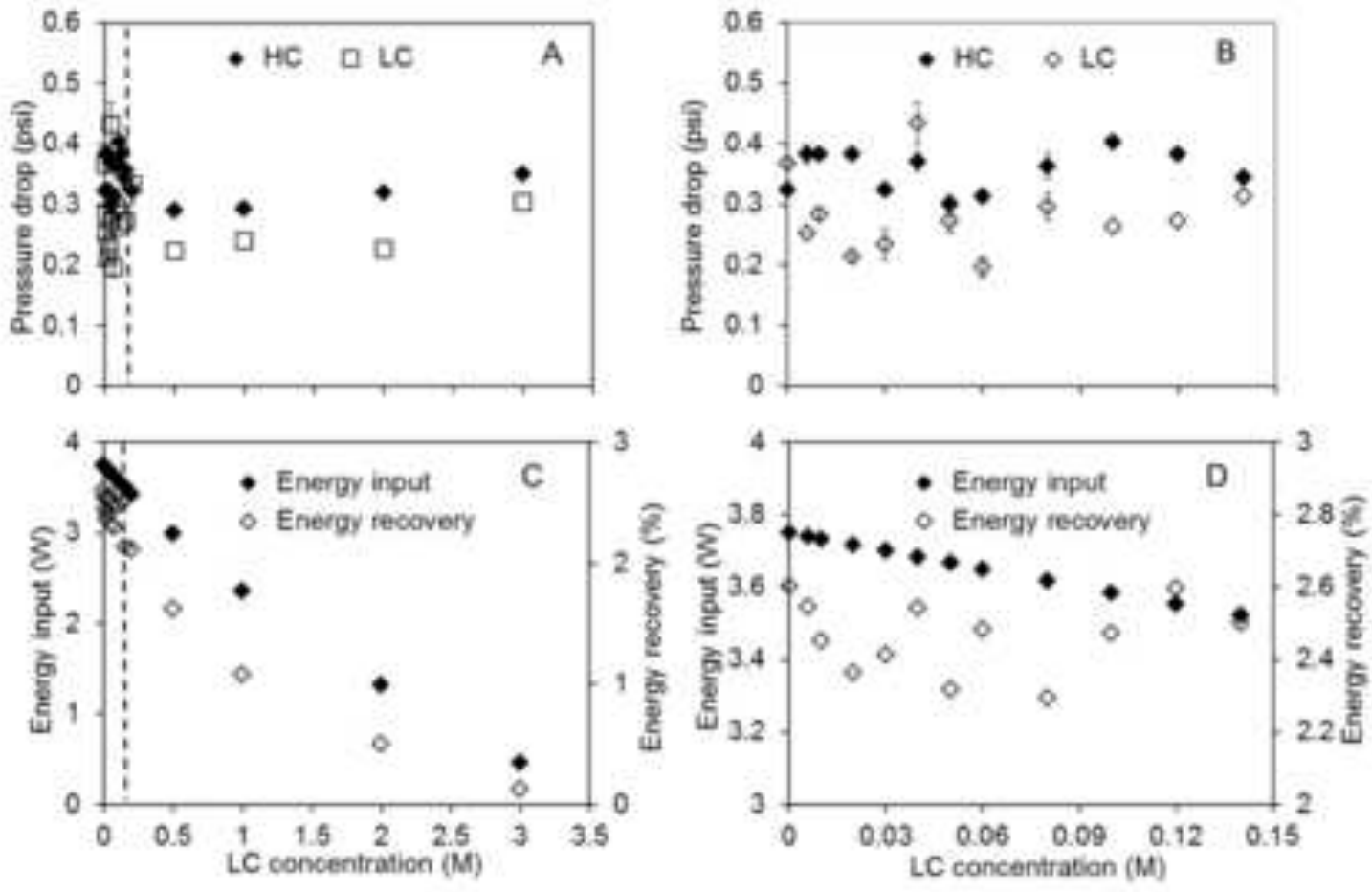

LC concentratian (M) 

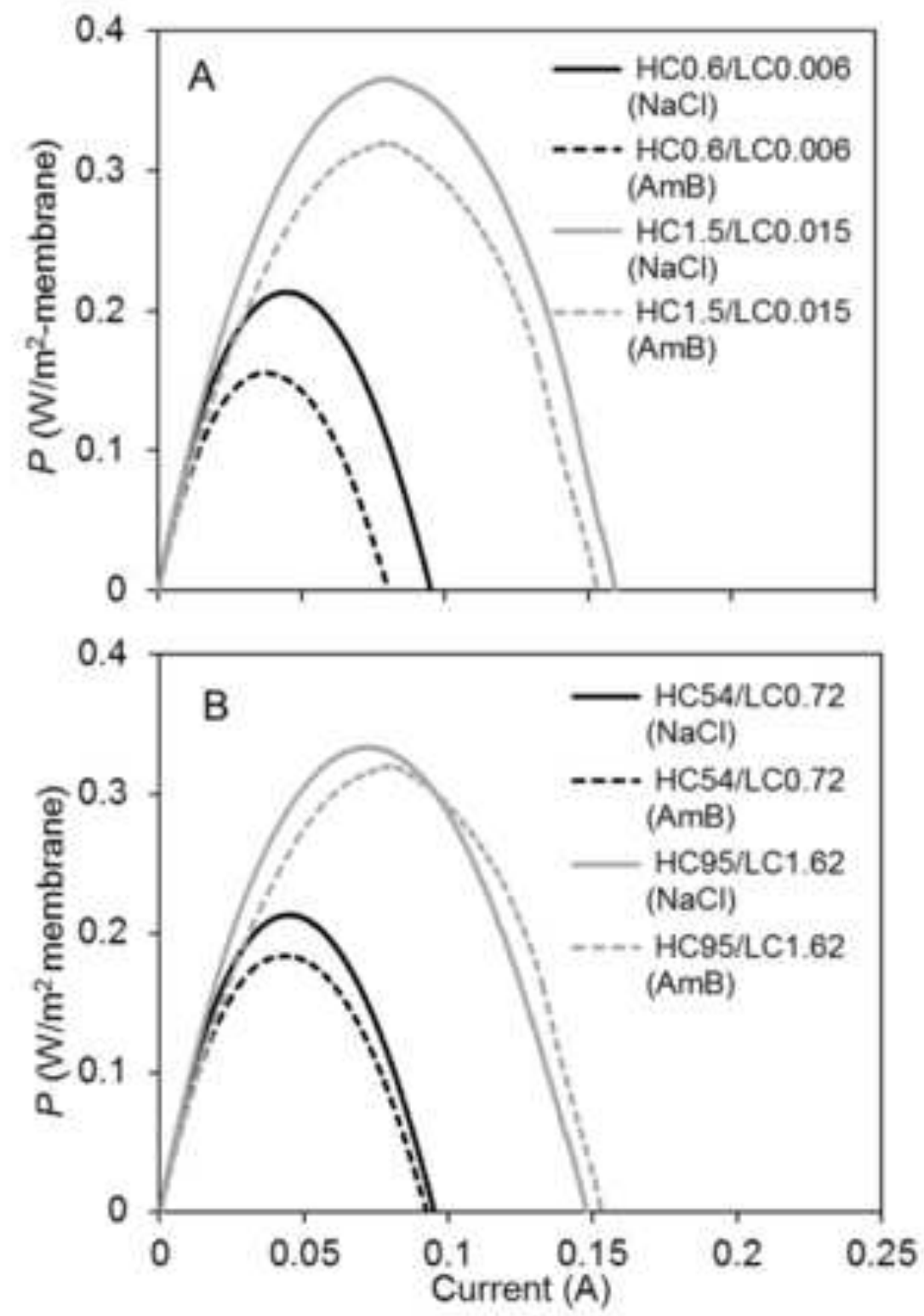
Figure- 6
Click here to download high resolution image

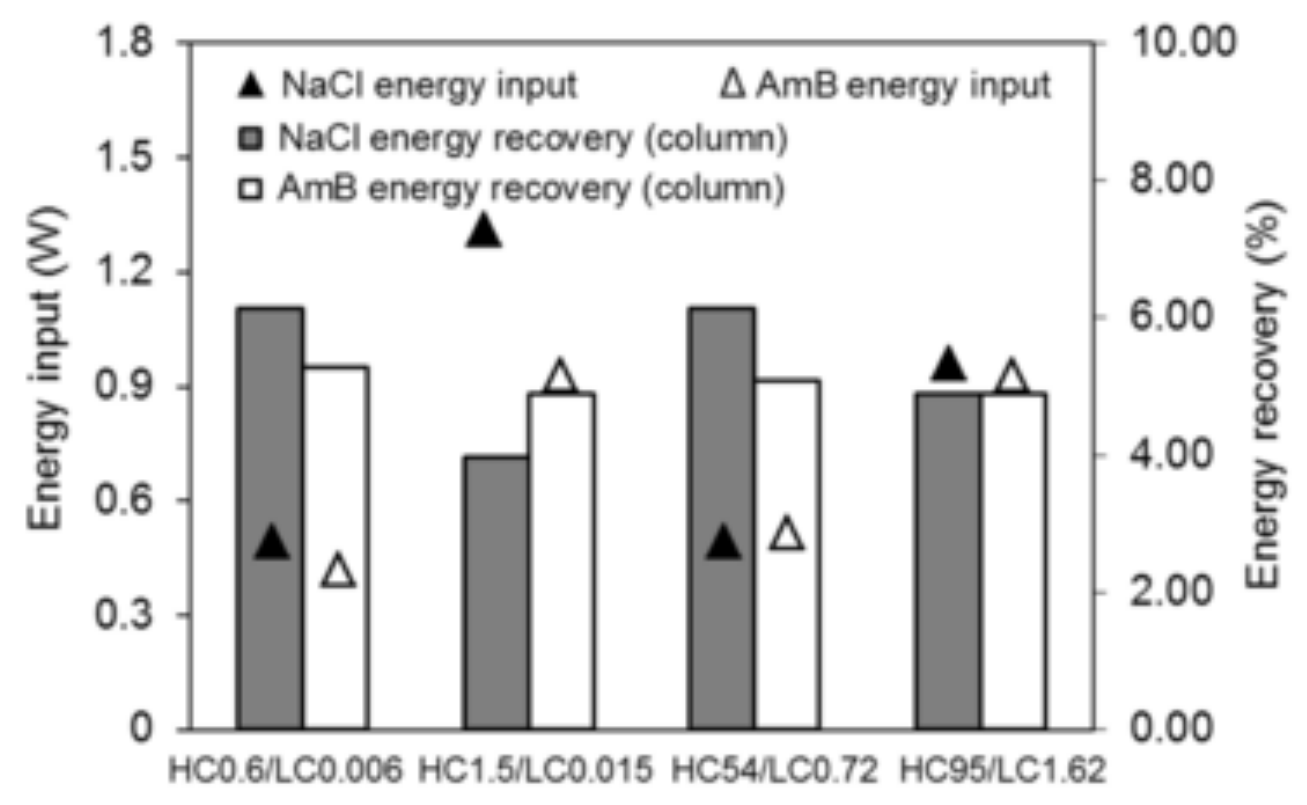

